\title{
Conceptual exposition of the effect of inflation on bank performance
}

\author{
Mohammed Umar ${ }^{1, ~ *, ~ D a n j u m a ~ M a i j a m a ' a ~}{ }^{2}$, Mohammad Adamu ${ }^{3}$ \\ ${ }^{1}$ Dept. of Economics and Development Studies, Federal University Kashere, Gombe State, Nigeria \\ ${ }^{2}$ School of General Studies, Abubakar Tatari Ali Polytechnic Bauchi, Bauchi State, Nigeria \\ ${ }^{3}$ Dept. of Economics, Bauchi State University, Gadau, Nigeria
}

Email address:

mumar@fukashere.edu.ng (M. Umar), danjumarabiuu@gmail.com (D. Maijama’a), talk2bom@gmail.com (M. Adamu)

\section{To cite this article:}

Mohammed Umar, Danjuma Maijama'a, Mohammad Adamu. Conceptual Exposition of the Effect of Inflation on Bank Performance. Journal of World Economic Research. Vol. 3, No. 5, 2014, pp. 55-59. doi: 10.11648/j.jwer.20140305.11

\begin{abstract}
Despite the fact that, banks can withstand the effects of inflation in the short run, since banking system mostly operates with reference to interest rate and maturity of financial instruments with less concern about the purchasing power of money. However, the banking system cannot absorb the shocks in the long run. The objective of this paper is to conceptually expose the effect of inflation on bank performance. To accomplish this objective, the paper reviews some theoretical and empirical works on the effect of inflation on financial sector performance. The paper found two divergent views. Thus, inflation has an adverse effect on banking sector performance and its spillover effect is very harmful to the overall economy. Inflation affect the purchasing power and bank exchange rate regime, opportunity cost of holding currency in the future, worsen loans policy, disrupt business plans and the equity holding performance of banks. While the other side of the argument states that inflation leads to an increase in bank performance as long as the banks can be able to anticipate future inflation and adjust interest rate to generate higher revenue than cost which leads to higher profit and performance as a result of adjusting the rate of interest.
\end{abstract}

Keywords: Inflation, Inflation Uncertainty, Monetary Authority, Bank Performance

\section{Introduction}

The effect of inflation on banking performance is an important and complex issue. It is important because it has been the primary concern of the investors, shareholders and lenders as well as the managers in planning their programmes for greater efficiency. It distorts the working of the price system and leads to inefficiency in the allocation of resources. Among the most important cost of inflation as it affect banking performance is the uncertainty about future inflation rates. Inflation uncertainty means price uncertainty in the future as a result of numerous factors, which is difficult to measure since it is not directly observed. An obvious measure of the uncertainty is the concept of variance in the mean which is criticized for the fact that an increase in the variance of inflation does not imply a corresponding rise in inflation uncertainty if available information allows agents to predict some of the increased volatility (Idowu \& Hassan, 2010).

However, recent studies measured inflation uncertainty using proxies obtained from either forecaster's estimates or models of inflation. These empirical results have discovered that inflation uncertainty affect the performance of the banking industry. Friedman (1977) argued that inflation uncertainty is costly since it distorts relative prices and raise the risk of doing business which leads to an adverse output/performance effect.

Empirical studies by Fischer (1993) in Kormendi and Meguire (1995) found that inflation uncertainty was relatively lower in economies with low inflationary rates. They concluded that inflation uncertainty increases mainly when monetary policy changes. The effects of monetary policy on inflation are ambiguous, and it will sometimes take for monetary policy to affect inflation. First of all, monetary policy affect the banking system; the effect will spill over to the real sector and finally a pass-through to inflation will be observed.

Most of the findings on this topic are rendered in empirical results that are technical for most people to comprehend. The theoretical and conceptual evidence on these relationships remains scanty. Therefore, this article conceptually exposed the effect of inflation on bank performance to guide financial authorities on how to minimize the rate of inflation and ensure 
financial stability. The study also add to the existing literature from the conceptual perspectives. It further differs from the previous studies in that the paper reviews empirical literature and expose the findings conceptually for easy understanding of the phenomenon especially by readers from another disciplines.

\section{Theoretical Nexus/Literature Review}

Economic theory can predict either positive, negative or zero effect of the trend of inflation on performance depending on the specific assumptions of the model. Given the absence of a theoretical consensus, the anticipated relationship between inflation and bank performance remains an empirical issue largely.

\subsection{The Friedman Hypothesis}

Friedman (1977) outlined an informal argument regarding the real effects of inflation. His point comes in two parts. In the first part of his hypothesis, an increase in inflation may induce an erratic policy response by the monetary authority and therefore lead to more uncertainty about the future rate of inflation. In the second aspect of Friedman hypothesis, the increasing uncertainty about inflation distorts the effectiveness of the price mechanism in allocating resources efficiently, thus leading to negative output effects. Ball (1992) formalized the Friedman argument and focused on the first aspect of the Friedman's hypothesis. In cash-in-advance model that allows for the precautionary savings and risk aversion, it shows that more inflation uncertainty can have a positive output performance effect.

Greater inflation will also tend to reduce resource efficiency as risk-averse individuals shorten the duration of contracts to minimize the losses arising from the deviations of actual from expected inflation. More frequent contract negotiations involve the diversion of scarce resources to the negotiation of contracts and away from more productive activities. Since savings and investment also require a contract of some kind, increase inflation uncertainty may reduce both planned savings and investment and therefore, lead to low bank performance. Volatile inflation rates also generate uncertainty about real interest rate, which also discourages savings and investment.

There also exist alternative theories regarding the relationship between inflation and financial sector performance. One alternative theory is the fiscal story: government combines high inflation with various restrictions on the financial sector to help fund expenditures (Bencivenga $\&$ Smith, 1992). As a result, they have both poorly developed financial systems and high inflation. The second story is a purely passive one: higher growth implies lower inflation, ceteris paribus. If financial services are a normal good, higher real activity also implies that rapidly growing economies have more rapidly developing banking system than slower growing economies. Hence, when observed over long periods, there may be a negative relationship between inflation and banking performance from this source alone.

\subsection{Conceptual Clarification}

Inflation is said to be the persistent rise in the general level of prices or a decline in the value of money over a period. Some economists often see inflation as an increase in the amount of money in circulation. Diversity in economic schools of thought generated a lot of arguments as to what causes inflation and inflation uncertainty. Friedman and Schwarts (1982) discovered a positive relationship between the inflation rate and money growth rate. Leftwich (1984) sees the causes of inflation volatility as the rate of increase in aggregate purchasing power in the economy that exceeds the rate of increase in the physical volume of goods and services available to be purchased. Dhakal et al. (1994) empirical findings show that changes in the money supply, the wage rate, the budget deficit and energy prices have direct inflationary effects in the USA. In addition to these variables, Paul (1997) reported exchange rate as a significant determinant of inflation in some countries.

Inflation is obviously determined in the short run if the demand for a commodity exceeds it supply while in the long run money supply seems to influence price changes (Abdulgafoor, 2000). Cheng and Tan (2002) found that besides the domestic factors which included private consumption, government expenditure, interest rate and money supply, external factors (Foreign Direct Investment, Technology Transfer, and Foreign Trade among others) also have a significant influence on Malaysian inflation which is even more severe compared to the internal factors. However, Saini (1982) studied inflation in some Asian countries and discovered that the growth of the money stock was not the primary source of inflation in the region.

\section{The Effect of Inflation on Bank Performance}

Empirical literature has investigated the effect of inflation on financial sector performance. This can be traced in the studies of Huybens and Smith (1999) who stated in a specific manner the emphasis of the recent theories on how increase in inflation effect credit market frictions with negative repercussions for financial sector performance. They further concluded that the volume of bank lending and performance in turn tend to decrease as the rate of inflation rises in a given economy. This further affect the volume of equity market trading in the long run. Boyd et al. (2001) found a non-linear, significant negative relationship between inflation and banking sector. They attested the existence of the rapid diminishing trend on banking lending activities as inflation increases marginally that leads to a discrete drop in the financial sector performance. It is further explained that the activities of bank lending rapidly reduces as inflation increases prior to its threshold level. This heavily affect the process of effective and efficient resource allocation in the financial sector. Ghazouani (2004) uses different countries data on inflation and financial sector performance indicators and the result shows that inflation has a negative incidence on 
financial sector performance even though there was no evidence of thresholds level after controlling for simultaneity and ignore biases on variables. Although, he argued "a marginal increase in inflation is harmless to stock market performance and banking sector development whatever the rate of inflation." It has also been stated that high inflationary rate reduces the financial assets' rate of return thereby creating frictions in the credit market, advancing fewer loans to the deficit spending units and advance negative effect on capital investment due to continues decrease in the agency activities of the banks (Choi, Smith \& Boyd, 1996). According to Rahman and Serletis (2009) the effect of inflation uncertainty on real economic activities using data from four industrialized countries. The result indicated differential impact of inflation on output growth in different countries studied. They argue that the effect depend on the structure and financial pattern in different countries. Moreover, English (1999) constructed a model and employ a cross sectional data and found a negative significant correlation between the country's financial services and the rate of inflation. In the words of Bettencourt (2010) high and uncertain inflation rate is found based on both time series and panel approaches to be detrimental to stable financial sector performance. Thus, low level of inflation serves as a prerequisite condition for attaining a stable and deep financial sector.

They concluded that the effect is more vulnerable to market-based financial system than bank-based financial system. Namazi and Salehi (2010) found a direct correlation between inflation and decrease of absorbed deposit and loan given capacities of banks. Therefore, any increase in the rate of inflation will lead to a corresponding decrease in banking system performance.

Despite a quite number of studies discovered a negative relationship between inflation and bank performance, in contrast, some studies revealed a positive relationship such researchers include Guru, et al (2002) who reported inflation as a macroeconomic variable that have a positive relationship with bank profitability and performance whereas a negative relationship exist between interest rate and bank profitability. Tan and Floros (2012) examine the effect of inflation on bank profitability, the result exhibits that "there is a positive relationship between bank profitability, cost efficiency, banking sector development, stock market development and inflation in China". Angeloni and Faina (2013) state that "monetary expansion and positive productivity shock increases bank leverage and risk".

Therefore, the empirical findings on the effect of inflations on banking performance is a mixed one, even though, a greater proportion of the findings revealed a negative relationship.

\section{How Inflation Affect Bank Performance}

Inflation affects bank performance as it transfers money from savers and investors to debtors. Therefore, the opportunity cost of holding currency in the future may discourage savings that will in turn affect the performance of banks. The amount of savings that would be available at the disposal of the banks will decrease as savers will prefer to invest in non-monetary capital projects to avoid losses expected from the declining purchasing power of money.

Another effect of inflation is that the purchasing power of currency becomes less valuable with the passage of time and that affect the bank exchange rate regime which worsen the trade performance of banks and further discourages export which leads to deficit bank balance and fall in the exchange rate.

Inflation usually disrupts business planning of banks. Budget becomes difficult because of the uncertainties created by the phenomenon in both prices of services and cost of inputs that reduced planned investment spending.

It worsens the loans policy which affects the performance of banks as a result of withdrawals by depositors from the banking system. This reduces bank resources thereby decreasing a large proportion of their profitability. In other words, it reduces the in and out flow of loans and advances since banks may not want to lend except at a higher interest rate which discourages borrowing by the deficit spending unit.

Inflation also affects the equity/shareholding performance of bank which reduces their equity capital thereby affecting the long-run efficiency of the banks. This is because the real share prices of banks are inversely related to both anticipated and unanticipated inflation.

\section{Conclusion}

Even though, banks can be able to withstand the effects of inflation at its initial stages, since banking system mostly operates with reference to interest rate and maturity of financial instruments ignoring the purchasing power of money. However, when the rate of inflation becomes stronger, the banking system cannot absorb the shock. This paper has examined the effect of inflation on bank performance. It has been observed that inflation has an adverse effect on banking sector performance and its spillover effect is detrimental to the overall economy. Inflation acts as a drag on performance as banks are usually compel to shift their resources from more productive activities simply to focus on profit and losses from currency inflation.

\section{Suggestions}

Since it has been argued that inflation increases frequently when monetary policy changes. Therefore, the monetary authorities should ensure a stable monetary policy in the economy. The monetary authorities should try to curtail and maintain the long run inflation rate at the low ebb which is one of the channels through which inflation volatility affect the performance of banks (Emmanuel \& Sunday, 2012). To curtail inflation, the monetary authorities should ensure increase in lending rate, reserve ratio requirements and selective credit control by the commercial banks and other credit institutions. On account of a lending rate instrument, the monetary 
authorities privatizes control over reserves procurement by turning the choice on the amount of reserves over the budgetary business sector. It takes immediate control over the setting of the lending rate (Hetzel, 2004). Using interest rate as a monetary policy instrument, control of monetary phenomenon does not bring about an exogenous problem of money shock in the economy. The policy that insure price stability work towards equality in the appreciation in real purchasing power required by the economy arising from nonneutrality in the monetary sense interacting with monetary shock as well as the inflation target impose by the monetary authorities in the economy (Hetzel, 2004). Extensive pursuance of inflation targeting as an alternative to curtailing the menace of inflation is another option that many monetary authorities in various economies have tries in the recent literature. Countries such as the New Zealand, Canada and the United Kingdom had declared a strong policies of inflation targeting to emphasized inflation control in the economies (Ammers \& Freeman, 1995). Furthermore, Lin and Ye (2009) study thirteen developing countries and established evidence that the policy tend to exhibit a significant effect in reducing the rate and uncertainty of inflation in the studies countries despite the heterogeneity encountered in the groups of the countries. Another study on how inflation targeting impact on the practicing central bank also shows a strong evidence on the reduction of inflation and inflation volatility especially in developing countries under the sample of the study and those countries that most enhance their monetary policy management (Mendonca, Jose \& Souza, 2012).

\section{Acknowledgements}

We would like to thank Associate Professor Dr. Nurwati Ashikkin Ahmad Zaluki of the Othman Yeop Abdullah Graduate School of Business (OYAGSB), University Utara Malaysia for her invaluable comments and observations. We also thank the anonymous referee and the editor, for their helpful comments on an earlier version of this article. Any remaining errors are the sole responsibility of the authors.

\section{References}

[1] Abdulgafoor, A. L. M. (2000). Commercial banking in the presence of inflation, Kuala Lumpur: A. S. Noordeen

[2] Ammers, J. \& Freeman, R. T. (1995). Inflation targeting in the 1990s: The experience of New Zealand, Canada and United Kingdom. Journal of Economics and Business, 47 (2), 165 192.

[3] Angeloni, I. \& Faina, E. (2013). Capital regulation and monetary policy with fragile banks. Journal of Monetary Economics, 60, $311-324$.

[4] Ball, L. (1992). Why does high inflation raise inflation uncertainty. Journal of Monetary Economics, 29 (3), 371 - 388.

[5] Bencivernga V. R. \& Smith, B. D. (1992). Deficit, inflation and banking system in developing countries: The optimal degree of financial repression. Oxford Economic Paper, 44, 767 - 790.
[6] Bettencourt, M. (2010). Inflation and financial development: Evidence from Brazil. Economic Modelling, 28, 91 - 99.

[7] Boyd, J. H., Levine, R. \& Smith, B. D. (2001). The impact of inflation on financial sector performance. Journal of monetary economics, 47, $221-248$.

[8] Cheng, M. Y. \& Tan, H. B. (2002). Inflation in Malaysia. International Journal of Social Economics, 29, 411 - 425.

[9] Choi, S., Smith, B., \& Boyd, J., (1996). Inflation, financial markets, and capital formation. Federal Reserve Bank of St. Louis Review 78, 9 - 35.

[10] Dhakal, D., Kandil, M., Sharma, S. \& Trescott, P. B. (1994). Determination of the inflation rates in the United States: A VAR investigation. The Quarterly Review of Economic and Finance 34 (1), $95-112$.

[11] Emmanuel, D. E. \& Sunday, C. S. (2012). The impact of inflation on stock market performance in Nigeria. American Journal of Social and Management Sciences, 3(2), 76 - 82.

[12] English, W. B. (1999). Inflation and financial sector size. Journal of Monetary Economics, 44, 379 - 400.

[13] Friedman, M. (1977). Novel lecture: Inflation and unemployment. Journal of Political Economy, 85, 451 - 472.

[14] Friedman, M. \& Schwatz, A. J. (1982). Monetary trends in the United State and the United Kingdom, Chicago: University of Chicago press

[15] Ghazouani, S. (2004). Does inflation impact on financial performance in the MENA region? Journal of Banking and Finance, $423-442$.

[16] Guru, B., Staunton, J. \& Balashanmugam, B. (2002). Determinant of commercial bank profitability in Malaysia. Paper presented at the $12^{\text {th }}$ annual Australian finance and banking conference Sydney, Australia, 16 - 17 December

[17] Hetzel, R. L. (2004). How do central banks control inflation? Federal Reserve Bank of Richmond. Economic Quarterly, 90 (3), $47-63$.

[18] Huybens, E. \& Smith, B. (1999). Inflation, financial markets and long run real activity. Journal of Monetary Economics, 43, $283-315$.

[19] Idowu, K. O. \& Hassan, Y. (2010). Inflation volatility and economic growth in Nigeria: A preliminary investigation. Journal of Economic Theory, 4 (2), 44 - 49.

[20] Kormendi, M. L. \& Merguire, S. (1995). Inflation and its unpredictability theory: an empirical evidence. Journal of Money, Credit and Banking, 25, $709-720$.

[21] Leftwich, R. H. (1984). A basic framework for economics, $\left(2^{\text {nd }}\right.$ ed). USA: Business publications, Inc

[22] Lin, S. \& Ye, H. (2009). Does inflation targeting make a difference in developing countries? Journal of Development Economics, 89, $118-123$.

[23] Mendonca, H. H. Jose, G. \& Souza, G. (2012). Is inflation targeting a good remedy to control inflation? Journal of Development Economics, 98, 178 - 191.

[24] Namazi, M. \& Salehi, M. (2010). The role of inflation in financial repression: Evidence from Iran. World Applied Science Journal, 11, 653 - 661. 
[25] Paul, M. T. (1997). Inflation in Asian countries: 1970 - 1992. Asian Economic Review, 248 - 275.

[26] Rahman, S. \& Serletis, A. (2009). The effect of inflation uncertainty, some international evidence. Journal of Economic Studies, 36, $541-550$.
[27] Saini, K. G. (1982). The monetarist explanation: The experience of six Asian countries. World Development, 10, 871 -884 .

[28] Tan, Y. \& Floros, C. (2012). Bank profitability and inflation: The case of China. Journal of Economics Studies, 39, 675 696. 